\title{
Pendampingan Bahaya Kanker Servik dan Pencegahannya Secara Islami
}

\author{
M. Fahli Zatrahadi $\left.{ }^{\star}\right) 1$, Darmawati Darmawati ${ }^{2}$, Miftahuddin Miftahuddin ${ }^{1}$, Suhaimi \\ Suhaimi ${ }^{1}$ \\ ${ }^{1}$ Bimbingan Konseling Islam, Universitas Islam Negeri Suska Riau, Indonesia \\ ${ }^{2}$ Ilmu Komunikasi, Universitas Islam Negeri Suska Riau, Indonesia
}

\section{Article Info \\ Article history: \\ Received May $12^{\text {th }}, 2021$ \\ Revised Jun $20^{\text {th }}, 2021$ \\ Accepted Jul 26 ${ }^{\text {th }}, 2021$}

\section{Keyword:}

Kanker Servik, Pencegahan Kanker servik, Pencegahan secara islami.

\begin{abstract}
Kanker serviks merupakan penyebab pertama kematian pada wanita, Untuk mengatasi masalah tersebut, di negara- negara maju, diagnosa secara dini terbukti mampu menurunkan insiden kanker serviks invasif dan memperbaiki prognosis. Deteksi dini dapat mengurangi kadar mortalitas dan morbiditas kanker serviks. Banyak wanita yang selayaknya menjalani skrining sering enggan untuk diperiksa oleh karena ketidaktahuan, rasa malu, rasa takut, dan faktor biaya. Adapun metode pengabdian yang digunakan adalah penyuluhan. Dengan materi Kesehatan Persektif Islam, materi Penyakit pada sistem reproduksi, kanker servik dan pencegahannya, Informasi dasar mengenai HIV/Aids, serta system reproduksi. Hasil pengabdian dengan menggunakan materi tersebut pada kegiatan Peyuluhan kanker Serviks dan pencegahannya secara islami bagi ibu ibu di dusun Pematang Kayu Arang Desa Pangkalan Baru Kecamatan Siak Hulu Kampar, maka hasil dari penyuluhan yang dilakukan tersebut dapat dikatakan baik dan mendapatkan respon yang sangat baik. Hal ini diperlihatkan dengan indikator Ibu-ibu jamaah mendengarkan meteri secara seksama dan penuh perhatian, dan meminta jalur fasilitas tes untuk terhindar dari kanker servik yang semula ditakuti pelaksanaan skriningnya.
\end{abstract}

\section{Corresponding Author:}

Zatrahadi, M. F.,

$\equiv$ m.fahlizatrahadi@uin-suska.ac.id

(C) 2021 The Authors. Published by Universitas Negeri Padang. This is an open access article under the CC BY-NC-SA license (https://creativecommons.org/licenses/by-nc-sa/4.0

\section{Pendahuluan}

Kanker serviks merupakan kanker terbanyak kedua di dunia pada wanita (Nindrea, 2017). Di seluruh dunia dan Afrika Selatan, insiden kanker serviks adalah sekitar 30 per 100.000 wanita (Fuadah et al., 2020), dan di Asia sekitar 265.884 wanita didiagnosa dengan kanker serviks dan 142.735 meninggal akibat kanker serviks (Dewi, 2017). Sementara di Indonesia, kanker serviks merupakan penyebab pertama kematian pada wanita (Rio \& Suci, 2017).

Diperkirakan setiap tahun, insiden sekitar 15,7 per 100.000 wanita Indonesia didiagnosa dengan kanker serviks (Suwiyoga, 2007). Untuk mengatasi masalah tersebut, di negara- negara maju, diagnosa secara dini terbukti mampu menurunkan insiden kanker serviks invasif dan memperbaiki prognosis. Deteksi dini dapat mengurangi kadar mortalitas dan morbiditas kanker serviks di seluruh dunia (Fajriah et al., 2018) dan secara internasional telah terbukti bahwa penanda unt uk kanker serviks secara dini, adalah dengan Papanicoloau (Pap) smear(Salim et al., 2020). 
Berbeda dengan di Indonesia, papsmear walaupun diperkenalkan sejak tahun 70-an belum mampu menjawab permasalahan kanker serviks (Suwiyoga, 2007). Hal ini disebabkan oleh kesadaran masyarakat di Indonesia untuk memeriksakan diri dengan tes pap smear sebagai upaya deteksi dini serviks masih rendah (Linadi, 2013). Masalah pap smear di Indonesia dikaitkan dengan akurasi, tehnik pengambilan dan pemeriksaan pap smear, sumber daya manusia, geografi, dan sikap wanita yang selayaknya menjalani skrining (Titisari et al., 2017).

Di negara berkembang, penggunaan secara luas program pengamatan leher rahim mengurangi insiden kanker leher rahim yang invasif sebesar 50\% atau lebih (Septadina, 2015).Kebanyakan penelitian menemukan bahwa infeksi human papillomavirus (HPV) bertanggung jawab untuk semua kasus kanker leher rahim. Perawatan termasuk operasi pada stadium awal, dan kemoterapi dan/atau radioterapi pada stadium akhir penyakit.

Hasil studi di Indonesia menyatakan bahwa para wanita yang selayaknya menjalani skrining sering enggan untuk diperiksa oleh karena ketidaktahuan, rasa malu, rasa takut, dan faktor biaya. Hal ini umumn ya disebabkan oleh masih rendahnya tingkat pendidikan dan pengetahuan masyarakat(Lestari \& Nurfajriah, 2020). Rata-rata wanita yang tidak menjalani skrining pap smear adalah wanita yang telah berusia lebih $\mathrm{d}$ ari 40 tahun dan tidak mempunyai pekerjaan.

Hal ini juga terjadi di kabupaten Kampar adanya indikasi kanker servik yang di keluahkan warga dusun pematang kayu arang desa pangkalan baru Kampar kiri, seperti kejadian tanggal 12 September 2015 terdapat warga yang terkena kanker servik dan membutuhkan penanganan medis lanjutan dikarenakan kanker servik dalam masa perkembangannya tidak menunjukkan tanda-tanda dan keluhan, barulah ketika sudah masuk stadium lanjutan masyarakat menyadarinya.

Tambahan pula risiko tinggi bagi seseorang untuk terkena kanker serviks adalah usia dekade 40-45 tahun (Nurwijaya, 2013). Sementara banyak wanita yang menjalani skrining adalah wanita yang berusia sekitar 30 tahun dan mempunyai pekerjaan (Sondang \& Hadi, 2019). Kanker leher rahim atau disebut juga kanker serviks adalah sejenis kanker yang 99,7\% disebabkan oleh human papilloma virus (HPV) onkogenik, yang menyerang leher rahim (Sondang \& Hadi, 2019). Di Indonesia hanya 5 persen yang melakukan Penapisan Kanker Leher Rahim, sehingga 76,6 persen pasien ketika terdeteksi sudah memasuki Stadium Lanjut (IIIB ke atas), karena Kanker Leher Rahim biasanya tanpa gejala apapun pada stadium awalnya. Penapisan dapat dilakukan dengan melakukan tes Pap smear dan juga Inspeksi Visual Asam Asetat (IVA). Berdasarkan latar belakang di atas, peneliti ingin melakukan pengabdian masyarakat guna memberikan pemahaman kepada masyarakat tentang bayahaya kanker servik dan pencegahan secara islami.

\section{Metode}

Kanker serviks merupakan kanker ganas yang terbentuk dalam jaringan serviks (organ yang menghubungkan uterus dengan vagina).Ada beberapa tipe kanker serviks. Tipe yang paling umum dikenal adalah squamous cell carcinoma (SCC), yang merupakan 80 hingga 85 persen dari seluruh jenis kanker serviks. Infeksi Human Papilloma Virus (HPV) merupakan salah satu faktor utama tumbuhnya kanker jenis ini. Tipe-tipe lain kanker serviks seperti adenocarcinoma, small cell carcinoma, adenosquamous, adenosarcoma, melanoma dan lymphoma, merupakan tipe kanker serviks yang langka yang tidak terkait dengan HPV.

Lokasi pengabdian di Dusun Pematang Kayu Arang Desa Pangkalan Baru Kampar Kiri. Perubahan Yang Akan di Amati :

1. Melihat perubahan tingkat kepahaman masyarakat tentang kanker servik cara pencegahan kanker servik

2. Masyarakat mengerti apa saja gejala dari kanker servik

3. Masyarakat memahami tempat pemeriksaan kanker servik dan pengobatan yang tepat jika sudah terkena kanker servik.

\section{Hasil dan Pembahasan}

Peyuluhan kanker Serviks bagi ibu ibu di dusun Pematang Kayu Arang Desa Pangkalan Baru Kecamatan Siak Hulu Kampar telah dilaksanakan selama 5 Sesi dalam 2 kali kegiatan. Tiap Sesi memakan durasi 2 × 60 menit yang dilaksanakan pada setiap hari Rabu. Adapun pelaksanaan peyuluhan tersebut dapat dideskripsikan sebagai berikut :

\section{Pelaksanaan Penyuluhan}


a. Materi Kesehatan Persektif Islam.

Pada dasarnya ibu ibu jamaah sudah mengetahui bahwa Islam mengajarkan agar umatnya selalu menjaga kesehatan. Namun, mereka dangat antusias ketika disajikan materi ini. Hal ini dapat terlihat ketika mereka memberikan banyak pertanyaan yang terkait dengan kesehatan dalam Islam.

b. Materi Penyakit pada sistem reproduksi

Pada umumnya, Ibu-ibu jamaah sudah pernah mendengar adanya berbagai pernyakit pada system reproduksi berupa nama dan keluhannya. Pada kesempatan materi ini, mereka manfaatkan untuk mendalami dan mengenal lebih jauh apa saja penyakit pada system reproduksi tersebut.

c. Kanker servik dan pencegahannya.

Materi ini disampaikan dengan secara gamblang. Ibu-ibu terlihat sangat memahami dengan baik, bahkan mereka meminta kiranya ada kesempatan pada kegiatan pengabdian berikutnya ada semacam test bagi mereka.

d. Informasi dasar mengenai HIV/Aids

Pada materi ini, ibu-ibu jamaah terlihat sangat antusias. Mareka sangat prihatin dengan kondisi pergaulan dan seks bebas, yang pada akhirnya mengantarkan orang tertular HIV/Aids. Mereka juga mendapatkan info bahwa penularan bukan hanya karena pergaulan dan seks bebas. Sehingga meeka dapat mengantisipasi. Selain itu, mereka juga diberi penyuluhan untuk turut serta memperhatikan dan tidak menjauhi jika ada dilingkungan mereka yang tertular (ODHA).

e. Sistem reproduksi.

Pada materi ini, ibu-ibu jamaah juga tetap memberikan pertanyaan seputar system reproduksi. Hal ini terjadi karena semua ibu-ibu jamaah telah berumah tangga dan tidak menganggab tabu, serta melihat bahwa system reproduksi adalah sesuatu yang sangat perlu diketahui agar dapat dijaga dan terhindar dari penyakit.

\section{Hasil Penyuluhan}

Selama 2 kali pertemuan dengan lima sesi materi pada kegiatan Peyuluhan kanker Serviks dan pencegahannya secara islami bagi ibu ibu di dusun Pematang Kayu Arang Desa Pangkalan Baru Kecamatan Siak Hulu Kampar, maka hasil dari penyuluhan yang dilakukan tersebut dapat dikatakan baik dan mendapatkan respon yang sangat baik.

Terdapat beberapa indicator yang dapat dijadikan argumentasi dari hasil baik ini:

a. Ibu-ibu jamaah mendengarkan meteri secara seksama dan penuh perhatian.

b. Ibu-ibu jamaah memunculkan banyak pertanyaan pada setiap materi, bahkan tidak jarang memunculkan gelak tawa, karena vulgarnya pertanyaan sesuai dengan materi yang disampaikan.

c. Ibu-ibu jamaah meminta tim pengabdian untuk memfasilitasi test kesehatan sesuai materi yang disampaikan bagi mereka pada kesempatan lain, seandainya memungkinkan.

d. Ibu-ibu jamaah meminta agar kegiatan yang sama dengan materi materi penting lainnya dapat dilanjutkan di tempat mereka.

\section{Faktor Penghambat dan Penunjang Penyuluhan}

a. Faktor Penghambat

1) Kegiatan penyuluhan dapat dilakukan hanya menyesuaikan dengan waktu kegiatan Ibu-ibu jamaah sehingga sangat terbatas. Hal ini dikarenakan mereka sibuk dengan aktivitas sehari, berkerja di kebun dan di ladang. sehingga mereka belum mendapat hasil maksimal dari proses penyuluhan yang telah dilaksanakan.

2) Tempat-tempat kegiatan yang dilaksanakan dari rumah ke rumah, bahkan ada rumahnya yang berupa pondok di dalam kebun. Sehingga tim pengabdian harus masuk ke dalam kebun dengan kondisi jalan dan suasana hutan yang sepi.

b. Faktor Penunjang

1) Antusiasme dan respons dari ibu-ibu jamaah pada setiap kegiatan dan materi yang disuluhkan. Bahkan ketika berakhirnya program penyuluhan ini, mereka bertanya kapan kegiatan serupa diberikan lagi kepada mereka.

2) Dukungan masyarakat yang kuat. Hal ini terlihat pada kehadiran ibu-ibu jamaah pada setiap kegiatan. 


\section{Kesimpulan}

Usia ibu-ibu jamaah yang rata-rata 40 tahun ke atas adalah usia yang beresiko untuk terganggunya kesehatan, terutama pada system reproduksi. Bahaya penyakit reproduksi, kanker serviks dan bahaya HIV/Aids adalah segala sesuatu yang harus dihindari. Hal ini dapat diketahui setelah mendapatkan penyuluhan akan bahaya dan resikonya sehingga mampu mencegah bahaya yang akan terjadi..

\section{Referensi}

Dewi, M. (2017). Sebaran Kanker di Indonesia, Riset Kesehatan Dasar 2007. Indonesian Journal of Cancer, $11(1), 1-8$.

Fajriah, F., Safarianti, S., \& Putra, R. K. (2018). Pengaruh Penyuluhan Kanker Serviks Terhadap Minat Wanita Multiparitas Untuk Melakukan Pemeriksaan Pap Smears di Desa Sukaramai Kota Banda Aceh. Jurnal Kedokteran Nanggroe Medika, 1(2), 27-32.

Fuadah, F., Rejeki, S., Triana, H., \& Purnasari, H. (2020). Deteksi Dini Kanker Serviks Melalui Pemeriksaan IVA Test Pada Wanita Usia Subur Di Desa Babakan Kecamatan Ciparay Kab Bandung. Prosiding Seminar Hasil Penelitian Dan Pengabdian Kepada Masyarakat Unjani Expo (Unex), 1(1), 47-49.

Lestari, M., \& Nurfajriah, S. (2020). Faktor-Faktor yang Berhubungan dengan Pengetahuan Wus tentang Manfaat Papsmear di Puskesmas Kecamatan Taman Sari. IMJ (Indonesian Midwifery Journal), 3(2).

Linadi, K. E. (2013). Dukungan suami mendorong keikutsertaan pap smear pasangan usia subur (PUS) di perumahan pucang gading semarang. Indonesian Journal of Reproductive Health, 4(2), 106617.

Nindrea, R. D. (2017). Prevalensi dan faktor yang mempengaruhi lesi pra kanker serviks pada wanita. Jurnal Endurance: Kajian Ilmiah Problema Kesehatan, 2(1), 53-61.

Nurwijaya, H. (2013). Cegah dan Deteksi Kanker Serviks. Elex Media Komputindo.

Rio, S., \& Suci, E. S. T. (2017). Persepsi tentang Kanker Serviks dan Upaya Prevensinya pada Perempuan yang Memiliki Keluarga dengan Riwayat Kanker. Jurnal Kesehatan Reproduksi, 4(3), 159-169.

Salim, E. S., Bindan, H., Pranoto, E., \& Dharma, A. (2020). Analisa Metode Random Forest Tree dan KNearest Neighbor dalam Mendeteksi Kanker Serviks. Jurnal Ilmu Komputer Dan Sistem Informasi (JIKOMSI), 3(2), 97-101.

Septadina, I. S. (2015). Upaya pencegahan kanker serviks melalui peningkatan pengetahuan kesehatan reproduksi wanita dan pemeriksaan metode IVA (Inspeksi Visual Asam Asetat) di wilayah kerja Puskesmas Kenten Palembang. Jurnal Pengabdian Sriwijaya, 3(1), 222-228.

Sondang, M., \& Hadi, E. N. (2019). Dukungan Suami Terhadap Perilaku WUS (30-50 Tahun) dalam Melakukan Pemeriksaan IVA di Wilayah Kerja Puskesmas Bondongan Tahun 2018. Gaster, 17(2), 200-216.

Suwiyoga, K. (2007). Kanker Serviks: Penyakit Keganasan Fatal Yang dapat Dicegah. Indonesian Journal of Obstetrics and Gynecology.

Titisari, I., Yanuarini, T. A., \& Antono, S. D. (2017). Faktor-Faktor Yang Mempengaruhi Sikap Pasangan Usia Subur (PUS) Melakukan Skrining Kanker Serviks Metode Iva Di Wilayah Kerja Puskesmas Kota Wilayah Utara Kota Kediri. Jurnal Ilmu Kesehatan, 5(2), 72-83. 